\title{
Ownership Structure and Performance of the Listed Tunisian Companies
}

\author{
Dr. Habib AFFES \\ Associate professor at the Faculty of Economics and Management \\ University of Sfax-Tunisia, Research Unit at Sfax University: LARTIGE \\ E-mail: habib.affes@yahoo.fr \\ Mrs. Nourchéne Hamza Hakim \\ Contractual Assistant at the Faculty of Sciences of Sfax \\ $\mathrm{PhD}$ student at the Faculty of Economics and management, Sfax \\ Research Unit at sfax university: LARTIGE \\ E-mail: nourchenehamza@gmail.com
}

Received: September 27, 2013 Accepted: November 1, 2013

doi:10.5296/ber.v3i2.4332 URL: http://dx.doi.org/10.5296/ber.v3i2.4332

\begin{abstract}
Across this study, we propose to study the role of the ownership structure in the discipline of executives and test if the managerial shareholdings, the concentration of property and the property of the institutional investors improve the performance of companies. Based on a sample of 17 Tunisian firms listed on the TSE between 2001 and 2005, we performed the variables regressions of ownership structure on the various measures of accounting and stock market performance.

Our results show that the concentration of ownership acts positively only on the accounting performance measured by ROE and the ownership of the institutional investors has a positive and significant effect on the accounting and stock market performance, while the managers shareholding has a negative and significant effect on the market performance measured by the Marris ratio.
\end{abstract}

Keywords: Ownership structure, Ownership of institutional investors, Concentration of ownership, Managerial shareholding, Performance. 


\section{Introduction}

The issue of governance has been the subject of a vast literature and continuous to draw the attention of the general public by economists, jurists but also by sociologists and management scientists.

The issue of governance appeared with Berle and Means (1932) and the separation of ownership and decision-making in the major listed companies with widespread shareholding. This separation causes the deterioration in the companies' performance. Charreaux (1997) defines corporate governance as "the set of the organizational mechanisms whose effect is to determine the powers and influence the management decisions that govern their behavior and define their discretionary space." Corporate governance is "the set of organizational mechanisms which define the leaders' discretionary space" [Charreaux, 1997].

This definition, which focuses on the dominant leadership role, enables to override the analysis of the relationship between the shareholders and directors and put back corporate governance in all the relations that a firm has with the shareholders as well as with bankers, employees, customers or the public authorities. Corporate governance is considered as the set of mechanisms for controlling the executive and defending the interests of all the stakeholders of the company. These mechanisms can be either of an external nature, such as the market of goods and services, the financial market and the leaders' labor market, or of a domestic nature, such as the mutual monitoring and the board of directors. The latter is considered as an important internal control mechanism of the leaders.

The internal mechanisms of corporate governance are defined as the way to control the firm using its structures and internal processes, for instance, the board of directors, the incentive and compensation systems, and ownership structure. These mechanisms of internal control, in their turn, benefited from a direct access to information and have an internal and direct view about leaders' behavior, which theoretically helps them monitor the managers better. The external mechanisms are represented by the market of goods and services, the financial market, the executives' labor market, the legal and regulatory environment as well as the lending financial institutions. The function of these mechanisms is to ensure a disciplinary sanction if there a non-compliance with the legal and contractual rules as well as with the competition rules. Several empirical studies attempted to identify the relationship between the control variables, particularly the variables of corporate governance internal mechanisms that are related to the ownership structure (majority, institutional, financial shareholders...) and to the features of the board of directors (composition, size and nature of the directors) and the firm performance.

The results are varied, which implies the absence of optimal characteristics that could increase the performance of any business. The effectiveness of the internal control mechanisms of the leaders or their impact on performance depends on the theoretical framework and the context of the study.

\section{Literature Review}

The theory of corporate governance has remarkably developed thanks to the agency theory which is broadly based on the managerial theory of Berle and Means (1932). The agency 
theory analyzes the consequences of the separation of management and property which creates conflicts. The agency theory deals with the way to resolve these conflicts by seeking the optimal type of contract.

This theory first appeared mainly in the work of Alchian and Demsetz (1972), Fama (1980) and Fama and Jensen (1983). However the article of Jensen and Meckling (1976) is the main reference on the issue of the agency relationships within the firm. Jensen and Meckling (1976) define an agency relationship as "a contract by which one or more persons (principal) engages another person (agent) to execute in his name any task that involves a assigning a power decision to the agent". The agency relationship between the shareholders and the managers can result in conflicts called agency conflicts due to the divergent interests of these people. The agency theory has analyzed only the relationship between the shareholders and the managers. This classical analysis is the shareholder-based vision of the corporate governance theory. The field of corporate governance goes beyond the relationship between the shareholders and the managers and must be defined much more broadly.

The new vision of corporate governance, more precisely the partnership vision helps overcome this analysis and put the issue of corporate governance throughout the firm's relations with the various partners including the banks, the customers, the employees, the government, etc... Over the past two decades, the poor performance, the scandals and bankruptcies of large companies have led the media, the investors, the governments, the regulators and the researchers to select a good governance system to discipline the managers and therefore improve the companies' performance (Charreaux, 1998).

Several theoretical studies found a link between ownership structure and performance. First, many researches tried to highlight the link between the management ownership and the firms' performance. The obtained results are contradictory. Some found a linear relationship, while others showed a nonlinear one (Demsetz and Lehn, 1985; Morck et al, 1988. McConnell and Servaes, 1990, and Hermalin and Weisbach, 1991). Secondly, ownership concentration plays a crucial role in the discipline of the leaders (Shleifer and Vishny 1986). An examination of its impact on performance leads to mixed results. Actually, some studies found a positive effect of the presence of the majority shareholders on performance (Berles and Means (1932), Shleifer and Vishny (1986)), while other studies concluded that there is no relationship between ownership concentration and performance (Holderness and Sheehan (1988)).

Investors play an important role in corporate governance. They are great monitoring staff for the company. Some authors found a positive relationship between the presence of institutional investors in the capital and the company's performance (McConnell and Servaes (1990) and Mohamed Omri). Since the work of Berle and Means (1932) and the identification of the problems caused by the separation of ownership and decision-making, many studies have focused on the study of the relationship between ownership structure and business performance. These studies emphasized that the managers can pursue objectives different from those of the shareholders, which are therefore contrary to the maximization of the market value of the shareholders' wealth. They add that the managers would submit to internal or external constraints that compel them to manage in accordance with this traditional objective. However, 
Demsetz (1983) argues that ownership / decision separation led to a decline in of the leaders' debits and there is no reason to think that a firm where its capital is wholly owned by its leader should be more efficient than a company having a diffuse capital. Currently, there are three main theories on this subject: "convergence of interests", "neutrality "and" persistence ".

\subsection{Thesis of the Alignment of Interests}

According to the theory of the alignment of interests initially supported by Berle and Means and reused by Jensen and Meckling (1976), the more percentage of the capital held by the managers is significant, the greater the deviation from the objective of the value maximization is low.

\subsection{The Neutrality Thesis}

In this thesis, Demsetz (1983) argues that capital ownership structure is an endogenous response to the process of profit maximization and depends on the firm's operating features and the pressure exerted by environmental, in other words, all the structures are equivalent.

The neutrality thesis advocated by Demsetz (1983) was taken up by Demsetz and Lehn (1985). Both authors reject any link between performance and ownership structure by studying the relationship between the accounting rate of return on equity and the concentration rate of the capital held by the major shareholders.

This test and this conclusion have been criticized by Morck, Shleifer and Vishny (1988). These authors identify a nonlinear relationship between the performance measured by Tobin's Q and the percentage of capital held by the board of directors, the body which is supposed to represent the capital held by the managers. Depending on the area the capital percentage considered, the effect of entrenchment or convergence of interests is dominant.

\subsection{The entrenchment thesis}

The entrenchment thesis set up by Morck, Shleifer and Vishny (1989) states that, contrary to the theory of the alignment of interests, the managers who have a solid majority of the capital escape any kind of control and then can manage a way opposite to the value maximization. Therefore, they will have a lower performance. However, these same authors (1988) using the Tobin's Q, as a performance indicator, identified a non-linear relationship between performance and the percentage of capital held by the managers. They concluded that in the area where the percentage exists, the effect of interest convergence outweighs the effect of rootedness or vice versa.

\subsection{Other Theses}

However, there are also nuanced positions. In particular, that of Fama and Jensen (1983) described as "mitigated neutrality ", based on the argument of natural selection. They concluded that the organizational forms that survive on time are effective and therefore leave the possibility of the existence of unsuitable ownership structures in the short term. Their analysis incorporates the elements of the leaders' control system. Morck, Shleifer and Vishny (1988) empirically concluded that the effect of the interest convergence outweighs the effect of 
the rootedness or vice versa depending on the area where the percentage of the capital held by the Board of Directors exists. To further understand the relationship between ownership structure and performance, we will be studying the effect of the leaders' shareholdings on the performance of the firm.

\subsubsection{The Effect of the managers' Shareholding}

The managers can be shareholders in the company. They have a percentage stake in the firm. The managers' shareholding is not a very recent phenomenon; it appeared with the agency theory. This theory assumes that the increase in the share capital held by the managers is a means of limiting the conflicts of interest between the managers and the shareholders.

An enormous amount of research tried to highlight the link that exists between the managers ' shareholding and the firms' performance. The obtained results are contradictory. Some found a linear relationship, while others showed a nonlinear one. The recent studies that sought the relationship between the firm's performance and the capital share held by the leaders came up with different viewpoints (Demsetz and Lehn, 1985; Morck et all, 1988. McConnell and Servaes, 1990 and Hermalin and Weisbach, 1991).

Most of the empirical studies dealing with the impact of the managers' shareholding on performance are based on five assumptions.

As Milton Friedman (1953) suggests that each event can be associated with an infinite number of explanations. The first hypothesis considers that the firm's performance increases with the managerial participation. The corresponding argument is that of the interest alignment. In other words, the greater the managers 'share is, the higher performance is, which means that there is a good protection of the managers and other owners' interests (Jensen and Meckling [1976]).

The second states that company's performance decreases with the capital share held by the managers and the managers' entrenchment and the capital cost explain this inverse relationship. A significant proportion of the capital held by the managers can reduce financial performance because these managers when having huge shares in the capital of the firm will have so much power that they will neglect the interests of the other stakeholders. The second argument is that the capital cost, which is, in fact, the growth of the capital share held by the managers, can result in the drop of financial performance since it increases the capital cost of the firm due to the decrease in the market liquidity or to the decline of the diversification opportunities on the part of the investors (Fama and Jensen [1983 page329]).

The third assumes that the firm's performance is a non-monotonic function with the participation of the managers in the capital. The fourth hypothesis suggests that the managers ' participation increases with the company's performance. The last one stipulates that the managerial participation has no effect on the company's performance and vice versa because of the natural selection and the mitigated neutrality.

On the one hand, ownership aligns the executives' interests with the shareholders' ones and increases performance, and on the other hand, it makes the rooting and easier and thus negatively affects performance which shows the complexity of the role of managers' 
stockholdings.

Several empirical studies contradicted the results concerning the existence of a linear relationship between the managers ' shareholding and the firm's performance and consider the possible existence of a nonlinear relationship. Non-linearity may be the result of the leaders' rooting. The study sample of McConnell and Servaes consists of two sub-samples. The first is composed of 1,173 firms with the analysis relating to the year 1976. The second sample includes 1,093 firms and refers to the year 1986. Both authors choose the capital share held by the managers as a proxy for ownership structure and the Tobin's $Q$ as a measure of performance. They included other variables known as of control such as spending on research and development, debt, spending on advertising and the asset replacement value. The results of McConnell and Servaes (1990) confirm the hypothesis that the ownership structure has a significant impact on the firm's value. They showed that the value of Tobin's Q increases and then decreases gradually as the property becomes concentrated in the hands of the managers.

Hermalin and Weisbach (1991) examine the managerial participation effect on Tobin's Q. Managerial participation is measured by the percentage of the shares held by the new and former CEOs of the Board of Directors. Using five-year panel data, the authors found a non-monotonic relationship between managerial participation and performance (positive between 0 and $1 \%$, decreasing between 1 and 5\%, increasing between 5 and $20 \%$ and decreasing beyond 20\%). Cho (1998) found the same non-monotonic relationship between Tobin's Q and management shareholding. However, he believes there are three equations in which the share capital held by the leaders depends on $\mathrm{Q}$, on investment and on a set of control variables.

Holderness et al. (1999) reproduce, for the years 1935 and 1995, the central aspects of the study carried out by Morck et al. and that of Demsetz and Lehn. Morck et al. found a significant positive relationship between performance and the managerial participation with a level of managerial ownership between 0 and $5 \%$, by contrast, Morck et al. found no statistically significant relationship beyond 5\%.

Some authors confirm the lack of a relationship between the structure of the managerial ownership and the firm performance (Demsetz and Lehn, Himmelberg et al (1999), and Paquerot Alexander (2000)). The study of Demsetz and Lehn focuses on 511 U.S. firms belonging to different sectors. The analysis is spread over five years from 1976 to 1980 . To assess the impact of the separation between property and decision on performance, the authors used a regression rate of return on equity measured for accounting purposes (ROA) on a broadcast indicator of capital. The empirical results showed no relationship between ownership structure and the rate of return on equity. This result confirms the neutrality thesis supported by Demsetz (1983). Himmelberg, Hubbard and Palia (1999) reviewed the relationship between property and performance using panel data of the Compustat large and small companies and found no relationship between the managers' shareholding and performance. Himmelberg et al. (1999) extended the study of Demsetz and Lehn by adding new variables so as to explain the variation in the ownership structure. Ownership structure is measured by the managers' shareholding; however, the Tobin's Q is the appropriate measure of performance although the 
authors confirm producing similar results if the ROA is the measure of performance.

Hypothesis 1: The positive relationship between the managers' shareholding and the company's financial performance.

\subsubsection{The Impact of Ownership Concentration}

Ownership concentration plays an important role in the managers' discipline (Shleifer and Vishny 1986). An examination of its impact on performance leads to mixed results. Indeed, some studies found a positive effect of the presence of the majority shareholders on performance while in others there is no relationship between ownership concentration and performance.

Berles and Means (1932) suggest the existence of a positive linear relationship between the capital concentration and the firm's value. In the same context, Shleifer and Vishny (1986) show the positive influence of capital concentration on the performance and therefore the importance of the role played by large shareholders. Agrawal and Mandelker (1996) suggest that the existence of large shareholders leads to a better monitoring of management and better performance especially when ownership is concentrated in the hands of institutional investors. In Japan, Kaplan and Minton, (1994), Morck, Nakamura and Shivdasani (2000), show that it is the major shareholders who control the leaders.

The German corporate governance system is also characterized by the presence of large shareholders. Gorton and Schmid, (2000), show that the value of the German firms improves when ownership concentration increases. Chen (2001) examines the relationship between ownership structure and the firm's value in China. The results show a positive relationship between a concentrated ownership and the company's value measured by Tobin's Q. Holderness and Sheehan (1988) suggest that there is no significant performance difference between firms with diffused capital and those of which capital is owned by a majority shareholder.

Similarly, Mulari and Welch, (1989), claim that the performance of closed organizations (with a small circulation of securities) is not different from that of the open ones (with a high diffusion of securities). Indeed, the performance of organizations with a high concentration of capital is similar to that of the organizations with a low concentration of capital. The presence of majority shareholders in the firms' capital positively affects their performance. Hence our hypothesis:

Hypothesis 2: The positive relationship between the percentage of the share capital held by the majority shareholders and performance.

\subsubsection{The Effect of the Institutional Investors' Ownership:}

The emergence of institutional investors, as major holders of financial assets with an increasing participation in capital markets, is one of the peculiarities of the current financial world, a feature likely to become more prominent in the coming years. Investors play an important role in corporate governance. They are great monitors for the company. The presence of institutional investors alters the relationship between ownership structure and corporate 
performance. The impact of monitoring by institutional investors on corporate performance is studied by more than one researcher. This impact is ambiguous (Dahia, Lonie and Power, 1998; Denis, Denis and Sarin, 1997).

McConnell and Servaes (1990) found a positive relationship between institutional investors' shareholding and the firm's performance measured by Tobin's Q. This is due to the fact that institutional investors buy stocks of the companies that have performed well. However, Pound (1988), Barclay and Holderness (1991); Loderer and Martin (1993) claim that institutional investors have impact on the firm's performance only when they are actively involved in corporate governance. These authors integrate the behavioral dimension of the institutional investors in the study of the previous relationship.

Among the various institutional investors, the pension funds were carefully considered. British companies are controlled and managed by pension funds. These are the institutional shareholders of these companies. Holding a large share of capital is considered as one of the mechanisms in solving the agency problems that arise when the leaders act against the shareholders' interests. Faccio and Lasfer (2000), by comparing the companies in which the pension funds are shareholders with a group of publicly traded companies in the UK, tested the hypothesis according to which control increases with ownership concentration and found that the pension funds reduce the conflicts of interest and improve the business performance. Due to the size of their shareholding, the UK pension funds are not known by their control and their voting in the annual general meeting is difficult

Smith (1996) found that the companies controlled by pension funds, such as CalPERS, have a much higher performance. The observation of the Tunisian economy, even if it is not developed enough to be compared to the American and French economies, shows that financial institutions (banks, insurance and investment companies ...) are the institutional investors of the Tunisian companies. They are involved in the control and management of companies through their financial contribution. An empirical study conducted by Mohamed Omri (2002) on this subject shows that the presence of institutional investors has a positive effect on the performance of the Tunisian firm.

The control functions of the managers may be assigned to specialized agents. In addition to the main shareholders, banks can be excellent monitors in supervising the managers' behavior. Management control by banks is very common in the Japanese companies. Moreover, the importance of the disciplinary role exerted by banks is considered as one of the determinant factors of the Japanese firms' effectiveness.

Financial institutions within the business groups in Japan called keiretsu are both creditors and shareholders. In other words, the Japanese firms belonging to a keiretsu are controlled by major banks that are both shareholders and creditors. Firm control through banks is rather a special form of governance in Japan. In fact, the involvement of the bank in the capital enables it to control the management of companies.

Contemporary literature was unable to deal with the fact that ownership structure of the financial institutions could affect their performance. Banks use their position as shareholders to 
increase the profitability of the Japanese company or increase the debt on behalf of these companies.

In this study, the author used panel data to show that if the bank is at the same time a shareholder and a creditor, this does not mean profit maximization. Paquerot and Alexander (2000) studied the effect of ownership structure on the firm's performance measured by the Sharpe ratio for the years 1991, 1992 and 1993. On the one hand, they found that the percentage of the capital held by institutional investors has a negative impact on the firm's performance. The institutional shareholders have no power to control the executives, the thing which confirms the entrenchment thesis.

On the other hand, they concluded that the capital concentration has no impact on the firm's performance. Moreover, they found that the percentage of the capital held by the managers has no effect on the firm's performance. Finally, we can conclude that the presence of institutional investors in the companies' capital significantly influences their performance.

Hence our hypothesis:

Hypothesis 3: There is a positive relationship between the percentage of the capital held by the institutional investors and performance.

\subsubsection{The Effect of Indebtedness:}

Economists and management researchers have not always found a consensus on the effect of indebtedness on the firm's performance.

The relationship between indebtedness and the firm's value is studied by more than one researcher (Modigliani and Miller, 1958, Ross, 1977, Jensen, 1986 and Opler and Titman, 1994).

Modigliani and Miller (1958) showed that indebtedness acts positively on the firm's value only in the presence of taxation.

Ross (1977) considers indebtedness as a signal of the firm's quality and its future profits. Indeed, indebtedness solves the conflicts that arise from the asymmetric information, hence its positive role. Under the assumption of free cash flow, Jensen (1986) assumes that indebtedness is a means of the managers' discipline which is value-generator and therefore acts positively on performance.

All these authors discuss the positive role of indebtedness on the firm's performance. However, indebtedness can act negatively on performance. Therefore, the relationship between performance and indebtedness is no longer linear, since it is sometimes positive and sometimes negative. Opler and Titman (1994) show that excess indebtedness can cause bankruptcy and direct and indirect costs which lead to the loss of confidence reflected in the loss of customers even before the period of receivership

For some people, the effect of indebtedness on performance is determined by a number of factors such as the ownership structure (Charreaux, 1997), the economic environment (Platt and Platt, 1994) and the field of activity (Titman and Opler, 1994). A study conducted by R J 
Davies et al (2005) on the effect of the indebtedness ratio on performance is built on the work of Morck et al (1988), McConnell and Servaes (1990), Modigliani and Miller (1963), Ross (1977) and Demsetz and Villalonga (2001).

Morck et al (1988) found the result where indebtedness has a negative and insignificant impact on the firm's value and hence its performance. This explains that the leaders of highly leveraged firms hold a large share of the capital. This idea is similar to that of G. Charreaux (1997). Demsetz and Villalonga, (2001), show that the negative relationship between indebtedness and performance may be due to inflation.

The indebtedness impact hypothesis

Hypothesis8: indebtedness has a negative impact on performance

\subsubsection{The Impact of the Firm'S Size}

The firm's size is an important determinant of companies' performance.

Management researchers often establish a relationship between firm's size and its performance. Actually, this influence is not new. The conducted researches in finance, and more specifically in corporate governance, consider this variable as a control variable which can be included in models related to the structure of ownership and the characteristics of the board of directors.

All the researches on the type of this relationship say that the larger the firms get, the higher their performance is. The researches conducted in financial management show that large size can cause the emergence of coordination problems of the management teams as well as conflicts of interest which makes these big companies no longer efficient and then have low levels of performance.

The results of the researches on the type of performance-size relationship show the non-linearity of the latter, as it is sometimes positive and sometimes negative. G.Charreaux distinguishes three types of companies: family-owned, controlled and managerial companies. There is a performance difference between these three types of companies. According Charreaux, the firm's performance does not depend on its size, but rather on the type of the company. Another study conducted by G.Charreaux on the holdings, the very large companies, shows that their performance is not different from that of other companies. The hypothesis on the impact of the firm's size

Hypothesis 9: The firm's size is positively associated with performance

\section{Summary of the assumptions}

ASSUMPTIONS

SIGN PROVIDED

H1: The relationship between the managers' shareholding and performance is positive +

$\mathrm{H} 2$ : The relationship between the majority shareholder and performance is positive +

H3: The relationship between the institutional investors' shareholding and performance is positive + 


\section{Macrothink}

Business and Economic Research

ISSN 2162-4860

2013, Vol. 3, No. 2

Control variables: H8: The relationship between indebtedness and performance is negative

H9: The relationship between the firm's size and performance is positive

\section{Methodology}

\subsection{Presentation of the Sample}

As far as the characteristics of our sample are concerned, the study focuses on 17 Tunisian companies listed on the TSE over a five-year period going from 2001 to 2005, which would mean 85 observations after excluding the banks, the insurance and financial companies and the property and real estate companies from our sample.

\subsection{Model, Variables and Measurements}

The aim of our research is to analyze the impact of the variables of ownership structure, namely the participation of the leaders in the capital, the concentration of ownership, the participation of the institutional investors in the capital, on the performance of the listed Tunisian companies.

\section{The Model}

$\mathrm{PER}=\mathrm{c}+\alpha 1 \mathrm{MAJ}+\alpha 2 \mathrm{MANA}+\alpha 3 \mathrm{INS}+\alpha 4 \mathrm{END}+\alpha 5 \mathrm{TAIL}+\varepsilon \mathrm{t}$

PERF: is calculated by the accounting measures (ROA, ROE) and the stock market measures (Tobin's Q and Marris)

MAJ: The percentage of the capital held by the majority shareholders

MANA: The percentage of the capital held by the manager

INS: The percentage of the capital held by the institutional shareholders

END: the company's indebtedness

TAIL: the firm's size.

Table 1. Variables and measurements.

\begin{tabular}{|l|l|l|}
\hline $\begin{array}{l}\text { Variables of Ownership } \\
\text { Structure }\end{array}$ & Variables & Measures \\
\hline \multirow{5}{*}{ SP Variables } & proppdg & \% of the capital held by the managers. \\
\cline { 2 - 3 } & propmaj & The part of the capital held by the majority shareholders. \\
\cline { 2 - 3 } & propinstit & The part of the capital held by the institutional investors. \\
\hline \multirow{4}{*}{ Variables de performance } & ROA & Net profit /Total Assets \\
\hline \multirow{2}{*}{ Variables de contrôle } & ROE & Net profit/Equity \\
\cline { 2 - 3 } & TOBIN & Market value of assets/Asset accounting value \\
\cline { 2 - 3 } & MARRIS & Equity market value /Equity accounting value \\
\hline & Lev & Indebtedness ratio \\
\cline { 2 - 3 } & LnTA & $\begin{array}{l}\text { The company's size measured by Neperian logarithm/total } \\
\text { assets }\end{array}$ \\
\hline
\end{tabular}


Table 2. Descriptive statistics

\begin{tabular}{|l|l|l|l|l|}
\hline Variables & Minimum & Maximum & Mean & Standard deviation \\
\hline Propmaj & 0,16 & 0,96 & 0,5940 & 0,21079 \\
\hline Proppdg & 0,00 & 0,17 & 0,0220 & 0,04703 \\
\hline Propinstit & 0,00 & 0,56 & 0,1874 & 0,17131 \\
\hline ROA & $-18,10$ & 73,78 & 6,5032 & 10,02117 \\
\hline ROE & $-90,10$ & 67,40 & 11,7066 & 18,12562 \\
\hline Q TOBIN & 0,31 & 3,99 & 1,3168 & 0,65665 \\
\hline Marris & 0,57 & 15,90 & 3,2174 & 2,47146 \\
\hline LEV & 5,27 & 98,50 & 47,2275 & 18,97193 \\
\hline LNTA & 9,58 & 14,06 & 11,0304 & 0,91524 \\
\hline
\end{tabular}

Table 2 shows that the Tunisian companies show: a high concentration of capital, (on average $59.40 \%$ ), a high debt ratio of about $48 \%$, a poor accounting performance and a better stock market one.

\section{Results and Interpretations}

Table 4. Results of the regression variables of ownership structure on the performance measures

\begin{tabular}{|l|l|l|l|l|}
\hline & Accounting Measures & \multicolumn{2}{l|}{ STOCK MEASURES } \\
\hline & ROA & ROE & TOBIN & MARRIS \\
\hline Constant & $-3,598$ & $19,287 * * *$ & 0,154 & $-1,583$ \\
\hline$\%$ of capital held by the majority shareholders & & $20,09 * *$ & & \\
\hline Managerial ownership & & & & $-10,223^{*}$ \\
\hline$\%$ of capital held by the institutional shareholders & $15,648^{* *}$ & $24,874 * *$ & $1,125^{* *}$ & $4,353^{* *}$ \\
\hline OverallLiabilities/Total Assets & $-0,350^{* * *}$ & $-0,512 * * *$ & $-0,0185^{* * *}$ & $-0,0749^{* * *}$ \\
\hline LN Total Assets & $2,147 *$ & & $0,165^{*}$ & $0,703 * *$ \\
\hline
\end{tabular}

*** Significant at $1 \%$; ** Significant at $5 \%$; $*$ Significant at $10 \%$

\subsection{The impact of Equity on Performance}

\subsubsection{The Participation of the Majority Shareholders}

The Tunisian listed companies are characterized by a concentrated ownership structure. Indeed, the average holding of the majority shareholders is around $60 \%$ (see Appendix 1).

The regression result of this variable over the various performance measures shows that the majority shareholders hae only a positive and significant impact on the return on equity (ROE), which confirms hypothesis H 2 (see Annex 2).

\subsubsection{Managerial Participation}

The managers' ownership of the Tunisian firms is, on average, around 2.2\% (see Appendix 1). This low weak rate below 5\% does not mean that the managers' interests of the listed Tunisian firms converge towards those of the shareholders. 


\section{Ml Macrothink}

Business and Economic Research

ISSN 2162-4860

2013, Vol. 3, No. 2

This is confirmed by the regression results of this variable on the various measures of the accounting (ROA, ROE) and the stock market (Tobin's Q, Marris) performance, since the part of the capital held by the managers has negative and significant effects on all the performance measures mentioned before. This does not confirm hypothesis H1 (see above).

\subsubsection{Participation of the Institutional Shareholders}

The institutional shareholders' participation in the equity of the listed Tunisian firms is, on average, $18.74 \%$ (Appendix 1).

On the basis of the regression variables of ownership structure on the accounting measures and the stock market performance, we find that institutional investors' shareholding has a positive and significant impact on all the performance measures. The effect on the accounting measures is greater than it is on the stock market ones. This confirms hypothesis $\mathrm{H} 3$.

\subsection{The impact of the Control Variables on Performance}

\subsubsection{Indebtedness}

The indebtedness rate is measured by the ratio of the total debt to the total assets. The average indebtedness rate of the listed Tunisian firms is, on average, around $47.22 \%$, but it is highly dispersed (see Appendix 1). According to the first regression category, we notice that the leverage has slightly significant negative effects on all the performance measures which confirms hypothesis $\mathrm{H} 8$.

Indebtedness for the Tunisian companies cannot help solve the problems of the shareholder-managers' interests after maximizing the firm's value.

\subsubsection{The Company's Size}

The average size of the Tunisian companies measured by the natural logarithm of the total assets has positive and significant effects on most of the accounting and stock market performance measures. This confirms hypothesis H9 which states that the larger the firm is, the better its performance will be. Performance is positively associated with the company's size.

Table 4. Results of the study and hypotheses checking

\begin{tabular}{|c|c|c|c|c|}
\hline & \multicolumn{2}{|c|}{ Accounting Performance } & \multicolumn{2}{|c|}{ Stock Market Performance } \\
\hline & (ROA) & (ROE) & (Q Tobin) & (MARRIS) \\
\hline \multicolumn{5}{|c|}{ Hypotheses on the variables relationship of ownership structure and performance } \\
\hline$\%$ Majority & & $+\mathrm{HV}$ & & \\
\hline$\%$ Managerial & & & & - HNV \\
\hline$\%$ Institutional & $+\mathrm{HV}$ & $+\mathrm{HV}$ & $+\mathrm{HV}$ & $+\mathrm{HV}$ \\
\hline \multicolumn{5}{|c|}{ Hypotheses on the relationships of the control variables and performance } \\
\hline Indebtedness & - HV & $-\mathrm{HV}$ & - HV & $-\mathrm{HV}$ \\
\hline Size & $+\mathrm{HV}$ & $+\mathrm{HV}$ & $+\mathrm{HV}$ & $+\mathrm{HV}$ \\
\hline
\end{tabular}

$(+)$ the relationship is positive and significant. 
(-) the relationship is negative and significant.

HV: Tested hypothesis, HNV: untested hypothesis

\section{Conclusion}

We tried to distinguish between the variables effects of the internal governance mechanisms, namely the ownership structure and control variables such as indebtedness and the firm's size, on the one hand, the impact on the accounting performance and, on the other hand, on the market performance.The regression results showed that the hypotheses on the governance variables are sometimes confirmed and sometimes not in the case of the Tunisian companies in our sample, but only for some measures.

Indeed, the impact of the ownership structure and indebtedness variables is not the same for all the performance measures.

The majority shareholding in the listed Tunisian firms has only a positive impact on the accounting performance measured by the ROE ratio, which confirms our hypothesis.

The managers' shareholding (managerial ownership) shows a negative and significant effect on the performance of the market as measured by Marris ratio, which does not validate our hypothesis.

The participation of the institutional shareholders in the capital of the Tunisian listed companies gave the expected signs, since the interests of these shareholders have positive effects on all the performance measures whether accounting or stock. This may reflect the quality of the institutional shareholders, which are in most cases banks, in controlling and the pursuing the firm's objectives.

Concerning the control variables in our model, we realized that: the indebtedness of the Tunisian listed companies has negative effects on most of the accounting and stock market performance measures, which does not validate the hypothesis on the disciplinary role of indebtedness for the managers.

The size of the listed Tunisian firms has positive effects on measures of the accounting and stock market performance, which confirms the hypothesis and the expected sign.

To better understand the link between the internal control mechanisms and the firm's performance, we are interested, in this research, in studying one single system of internal control namely the ownership structure and its influence on the performance of the firm.

Thus, for ownership structure, we first dealt with the effect of the managers' ownership on performance. This served as the basis for several theories the most important of which are the convergence of interests, rootedness and neutrality. The most common conclusion was that the first two theories coexist and, depending on the level of the managers' ownership, either of them dominates.

Secondly, we discussed the concentration effect and the type of ownership and opted for the supremacy of the ownership benefits of the majority and institutional shareholders. In fact, the 
effect of this on the firms' performance is generally positive.

We tried to test the hypotheses about the effect of ownership structure on the firm's performance. This research used a sample of 17 Tunisian companies listed on the stock exchange in Tunis between 2001 and 2005. We found that the managers' ownership has a negative effect on performance as it is measured by Tobin whereas for the other measures it has no effect or it is not significant. We also found that the ownership of

the institutional and the majority shareholders has a positive effect.

Our study could have been more extensive if we had had data on the external control mechanisms which, beside the internal mechanisms, can have a very important role in the management discipline. These external mechanisms include mainly the legal and regulatory environment, the market for goods and services, the financial market and the managers' labor market.

\section{References}

Agrawal, A., \& Knoeber, C. R., (1996), Firm performance and mechanisms to control agency problems between managers and shareholders", Journal of Financial and Quantitative Analysis, 31,377-397.

Alexander H. et Paquerot M., (2000). Efficacité des structures de contrôle et enracinement des dirigeants", Finance, Contrôle, Stratégie, 3(2), 5-29.

Bhagat S. and Black B., (1999). The uncertain relationship between board composition and performance", Business Lawyer, vol.54, pp.921-963.

Bhagat S and Black B., (2001). Board independence and long-term firm performance", working paper, University of Colorado.

Barclay M.and Holderness C. (1991). Negociated blocktrades and corporate control”, Journal of Finance, 46, 861-878.

Baysinger B., \& Butler H., (1985). Corporate governance and the board of directors: performance effects of changes in board composition, Journal of Law, Economics, and Organisations, 1, 101-124.

Borokhovich K., Parrino R., \& Trapani T., (1996). Outside directors and CEO selection, Journal of Financial and Quantitative Analysis, 31, 337-355. http://dx.doi.org/10.2307/2331395

Boyd B., (1994). Board control and CEO compensation, Strategic Management Journal, 15, 335-344. http://dx.doi.org/10.1002/smj.4250150502

Boyd B. K. (1995). CEO Duality and firm performance: a contingency Model, Strategic Management Journal, 16, 301-312. http://dx.doi.org/10.1002/smj.4250160404

Charreaux G. et Pitol-Belin J-P., (1990). Le conseil d'administration, Vuibert Gestion

Charreaux, G., (2000). Le conseil d’administration dans les théories de la gouvernance, Revue 
du financier, N 31, Décembre, 6-17.

Core J., Holtausen R., \& Larcker D., (1999). Corporate governance, Chief executive officer compensation, and firm performance, Journal of Financial Economics, 51,371-406. http://dx.doi.org/10.1016/S0304-405X(98)00058-0

Denis, D., \& Sarin A., (1999). Ownership and board structures in publicly traded corporations. Journal of Financial Economics, $\quad 52, \quad$ 187-224. http://dx.doi.org/10.1016/S0304-405X(99)00008-2

Eisenberg T., S. Sundgren, \& M. T. Wells, (1998). Larger board Size and decreasing value in small firms. Journal of Financial Economics, vol. 48(1), 35-54. http://dx.doi.org/10.1016/S0304-405X(98)00003-8

Fama, E. (1980). Agency problems and the theory of the firm, Journal of Political Economy, 88, 288-307. http://dx.doi.org/10.1086/260866

Godard, L. (2002). La taille du conseil d'administration : déterminants et impact sur la performance, Revue sciences de gestion, 33, 125-148.

Godard, L. (1998). Les déterminants de choix entre un conseil d'administration et un conseil de surveillance, Finance Contrôle Stratégie, 1(4), 39-61.

Gorton, G., \& Schmid, F. A., (2000). Universal banking and the performance of German firms, $\begin{array}{lllll}\text { Journal of } & \text { Financial } & \text { Economics, } & 58,\end{array}$ http://dx.doi.org/10.1016/S0304-405X(00)00066-0

Hermalin, B. E., \& Weisbach M. S., (1988). The determinants of board composition, Rand Journal of Economics, 19, 589-606. http://dx.doi.org/10.2307/2555459

Hermalin, B., Weisbach, M., (1991). The effects of board composition and direct incentives on firm performance,Financial Management, 20,101-112. http://dx.doi.org/10.2307/3665716

Hermalin, B. E., \& Weisbach M. S., (2001). Board of directors as an endogenously determined institution: a survey of the economic literature «, Rand Journal of Economics, March, 589-606.

Jensen M. C. (1993). The modern industrial revolution, exit, and the failure of internal control systems, The Journal of Finance, vol.XLVIII, n3, 831-880. http://dx.doi.org/10.1111/j.1540-6261.1993.tb04022.x

Jensen, M., \& W. Meckling (1976). Theory of the firm: Management behavior, agency costs and ownership structure, Journal of Financial Economics, 3, 305-360. http://dx.doi.org/10.1016/0304-405X(76)90026-X

Kaplan, S., \& Minton, B., (1994). Appointments of outsiders to Japanese boards-determinants and implications for managers, Journal of Financial Economics, 36, 225-258. http://dx.doi.org/10.1016/0304-405X(94)90025-6

Klein, A, (1998). Firm performance and board committee structure. Journal of Law and Economics, 41, 275-303. http://dx.doi.org/10.1086/467391 
Lipton, Martin, \& Jay Lorsch (1992). A Modest Proposal for Improved corporate governance, Business Lawyer, 48(1), 59-77.

MacAvoy, Paul W., S. Cantor, J.Dana, \& S. Peck, (1983). Ali proposals for increased control of the corporation by the board of directors: An economic analysis. In Statement of the Business Roundtable on the American Law Institute's Proposed. Principles of corporate governance and Structure: Restatement and Recommendations, Exhibit C-1.

Mace, L., (1986). Directors, myth and reality. Boston. Harvard Business School Press.

Omri A., \& Mehri B, (2003), African Administrative Studies, 60, 1-17

Pearce J. A., \& S. A. Zahra, (1992). Board composition from a strategic contingency perspective, Journal of Management Studies, 29(4), 411-438. http://dx.doi.org/10.1111/j.1467-6486.1992.tb00672.x

Perry, T. (2000). Incentive compensation for outside directors and CEO Turnover, Working paper, Arizona State University.

Prevost A. K, Rao R. P et Hussain M, (2002). Determinants of board composition in New Zealand: a simultaneous equations approach,Journal of Empirical Finance, 9, 373-397. http://dx.doi.org/10.1016/S0927-5398(02)00002-6

Pichard-Stamford J.-P., (1998). La légitimation du dirigeant par le réseau des administrateurs, Actes des XIV èmes journées nationales des I.A.E., tome2, Nantes, 389-407

Rapport Bouton, pour un meilleur gouvernement des entreprises cotées, AFEP/AGREF-MEDEF, septembre, 2002.

Rapport Vienot, Le conseil d'administration des sociétés cotées, AFEP-CNFP, juillet, 1995.

Rapport Vienot, Rapport du comité sur le gouvernement d'entreprise, AFEP-MEDEF, juillet, 1999.

Rosenstein S., \& Wyatt G., (1990). Outside directors, board independence, and shareholder wealth, Journal of Financial Economics, August, 175-192. http://dx.doi.org/10.1016/0304-405X(90)90002-H

Rosenstein S., \& Wyatt G., (1997). Inside directors, board effectiveness, and shareholder

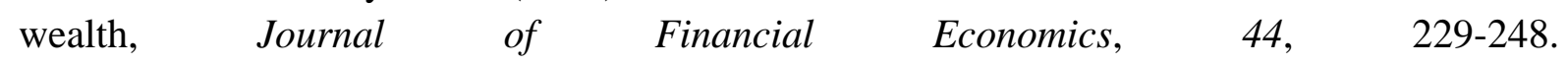
http://dx.doi.org/10.1016/S0304-405X(97)00004-4

Shleifer, A., \& Vishny, R., (1997). A survey of corporate governance, Journal of Finance, 52, 737-784. http://dx.doi.org/10.1111/j.1540-6261.1997.tb04820.x

Vaananen J., (2005). Corporate governance: Mechanisms to align interests of owners and managers, Business Strategy and International Business, 1-36

Vance, Stanley C., (1964). Board of directors: Structure and performance. Harvard Business School Press, Boston, MA. 


\section{Macrothink}

Business and Economic Research

ISSN 2162-4860 2013, Vol. 3, No. 2

Weisbach M., (1988). Outside Directors and CEO Turnover, Journal of Financial Economics, 20, 431-460. http://dx.doi.org/10.1016/0304-405X(88)90053-0

Williamson O. E. The Economic Institutions of Capitalism, The Free Press: New York, 1985

Yermack D., (1996). Higher market valuation of companies with a small board of directors, Journal of Financial Economics, 40(2), 185-211. http://dx.doi.org/10.1016/0304-405X(95)00844-5

\section{Copyright Disclaimer}

Copyright reserved by the author(s).

This article is an open-access article distributed under the terms and conditions of the CreativeCommons Attribution license (http://creativecommons.org/licenses/by/3.0/). 